\title{
Controlled protein hydrolysis with immobilized alkaline endo-protease
}

\begin{abstract}
Enzymatic hydrolysis is used to enhance the functional properties of proteins; the modified proteins exhibit improved solubility, lower hydrophobicity and viscosity; but high cost and lower stability of proteases pose problems in their commercial use. In current work, different endo-proteases were screened for proteolytic activity and 89L (alkaline protease) was selected based on higher specific activity. Glutaraldehyde coupling was used for immobilization with CR20 resin as support matrix; various parameters such as glutaraldehyde concentration (1\%), activation time (16hrs), enzyme loading $(4 \mathrm{mg} / \mathrm{ml}$ of resin) and coupling time ( $2 \mathrm{hrs})$ were optimized for maximum immobilization efficiency. Immobilized preparation exhibited high catalytic activity i.e. 9260 Casein Digesting Units per $\mathrm{ml}$ with improved operational and storage stability. Soy proteins, whey proteins, bovine serum albumin (BSA) were subjected to controlled protein hydrolysis using immobilized 89L. Hydrolysis reaction with BSA revealed substrate concentration is inversely proportional to degree of hydrolysis. Gel permeation chromatography analysis of BSA and soy protein hydrolysates depicted formation of peptides in the range of $1-10 \mathrm{kDa}$ and $<1 \mathrm{kDa}$. MS analysis confirmed presence of smaller peptides with molecular weight around $1 \mathrm{kDa}$. Optimum hydrolysis of soy proteins was obtained in batch mode with $1: 10$ enzyme to substrate ratio at $50^{\circ} \mathrm{C}$ in 200 min with $16 \%$ degree of hydrolysis. Packed bed column hydrolysis produced homogeneous hydrolysates for 15 cycles without any loss of enzymatic activity. Thus, protein hydrolysis reaction can be customised using immobilized $89 \mathrm{~L}$ to obtain peptides with desired molecular weight distribution.
\end{abstract}

Keywords: alkaline protease, glutaraldehyde, hydrolysis, peptides, soy protein, hydrophobicity, endo-proteases
Volume 2 Issue 2 - 2017

Vaze RG, Odaneth AA, Lali AM
DBT-ICT-Centre for Energy Biosciences, India

Correspondence: Annmmma A Odaneth, Assistant Professor in Biochemistry, DBT-ICT Centre for Energy Biosciences, Institute of Chemical Technology, Nathalal Parikh Marg, Mumbai-400 019, Mahrashtra, India, Fax +9|-22-24I456|4, Tel +9|-22-336|23|2, Email a.dbtceb@gmail.com

Received: October 27, 2016 | Published: February 23, 2017
Abbreviations: CDU, casein digesting units; TNBS, 2,6,6-trinitrobenzenesulfonic acid; TCA, trichloro acetic acid; GPC, gel permeation chromatography; BSA, bovine serum albumin; SPI, soy protein isolate; MS, mass spectrometer

\section{Introduction}

Protein modification or texturing is necessary since, during extraction process, proteins are exposed to various harsh conditions like acid/alkali treatment, elevated temperature and pressure which hampers their quality under severe conditions proteins may lose their functionality. Physiological properties of proteins depict their behaviour and performance in food systems and thus render functionality to protein. ${ }^{1}$ Hence protein conditioning is necessary in order to improve functional value of processed proteins. Proteins could be modified chemically, enzymatically or using heat treatments. ${ }^{1}$ Wang Wei et al. ${ }^{2}$ studied collagen hydrolysis with thermal and enzymatic treatment, enzymatic cleavage gave reproducible yield, protein content and peptide profile, while in thermal process, protein digestion was difficult to control which cause variation in peptide profiles. ${ }^{2}$ Use of chemical modifications for proteins, like acetylation or succinylation cause change in net charge on protein surface to improve solubility, but alteration in native amino acids results in poor digestibility. ${ }^{1}$ Thus utilization of proteases for improving protein functionality remains as suitable and sustainable method of choice. ${ }^{3}$

Functional properties of modified proteins are influenced by molecular weights of peptides present in hydrolysates, ${ }^{4}$ which necessitates controlled protein hydrolysis in order to obtain peptides with specified functionality. ${ }^{5}$ Pintado et al. ${ }^{6}$ reported, manipulation of protein digestion with protease provides route for production of growth supportive peptides from whole whey proteins which reduce addition of expensive nutrients to growth medium. These hydrolysed proteins also prevent precipitation and improve thermal sensitivity of product. ${ }^{6}$ On the other hand, Wang et al. ${ }^{3}$ demonstrated use of controlled enzymatic hydrolysis of egg yolk protein which improved solubility, foaming and emulsification capacity of proteins. ${ }^{3}$ Soy proteins are traditionally known for their high nutritional value, which include major soy proteins Glycinin, $\beta$-conglycinin, albumins, enzymes and protease inhibitors. ${ }^{7}$ However, soy protein isolates are generally associated with presence of soy allergens, bitter taste, indigestibility due to protease inhibitors etc. which necessitates their modification. Extensive proteolysis can form bitter tasting peptides which reduce the acceptability of product, ${ }^{8}$ thus tailoring enzymatic hydrolysis in essential step in production of high quality hydrolysates. Various reports are available which signifies role of enzymatic hydrolysis on improving functional properties of soy proteins. ${ }^{9-15}$ Along with soy proteins, whey derived proteins are also popular among food proteins owing to their health benefits. Enzymatic hydrolysis have been employed for modifying whey proteins in order to enhance their bioactivity. $6,16,17$

However, use of soluble enzyme on commercial scale increases cost of entire process and requires prolonged time for obtaining higher degree of hydrolysis. ${ }^{18}$ Additionally, recovery of protease from reaction mixture is difficult ${ }^{19}$ as substrates (proteins), products (mixture of peptides \& some proteins) and enzyme itself (protease) 
possess similar physical properties. Thus, attempts were made to use ultra filtration membranes which retain protease on its surface with simultaneous removal of hydrolysed peptides from permeate stream allowing continuous production of hydrolysates. Such membrane reactors have been employed for hydrolysis of various protein substrates soy proteins, ${ }^{20}$ casein,${ }^{21}$ haemoglobin ${ }^{22}$ and whey proteins. ${ }^{23}$ Though, application of membrane reactors have some disadvantages like thermal and shear stress deactivation of enzyme, reduced enzymatic activity due to enzyme leakage through membrane and fouling on membrane surface. Also, proteases are susceptible to self-cleavage termed as autolysis ${ }^{24}$ which is not observed in case of other enzymes like cellulases, lipases, laccases etc. In order to overcome these drawbacks of employing soluble proteases, alternatively these proteases can be immobilized on solid supports and used for production of protein hydrolysates. Proteolytic reactions can be regulated easily by using immobilized enzymes which help in improving stability, repetitive use and ease of separating product thereby controlling hydrolysis and preventing contamination of end-product with proteases. ${ }^{25-27}$ Various immobilization techniques namely physical adsorption, covalent binding, entrapment, crosslinking and encapsulations are conventionally used for enzyme immobilization. ${ }^{26,28}$

Out of all available methods, covalent immobilization has several advantages such as, higher retention of catalytic activity, lower leaching and enhanced stability in reaction media. Glutaraldehyde coupling is a simple, robust immobilization method which enhances enzyme stability. ${ }^{29}$ Glutaraldehyde is easily available at cheaper rates it reacts rapidly with amino groups to form thermally and chemically stable complexes. ${ }^{30}$ Researchers have reported suitability of glutaraldehyde coupling for different types of proteases. ${ }^{30-34}$ Random glutaraldehyde activation followed by protease coupling may lead to low or multiple binding which adversely affects protease activity. Hence, current work was focused on systematic study of various parameters, to obtain maximal proteolytic activity after immobilization. Immobilized serine protease was further utilized for controlled hydrolysis of proteins; correlation between residence time and its control on degree of hydrolysis was determined. The efficiency of immobilized protease was analyzed for continuous production of protein hydrolysate in packed bed column.

\section{Materials and methods}

\section{Materials}

Different endo-proteases (6L, 7L, 15L, 26L and 89L) were obtained from Genencor (Sweden) and were used as received. Folin \& ciocalteu's reagent, trichloro acetic acid, sodium bicarbonate was obtained from Himedia Ltd. Synthetic resin Diaion CR20 was a gift from SRL (Italy). Glutaraldehyde solution $(25 \% \mathrm{w} / \mathrm{w})$ was purchased from SD fine chemicals Ltd (Mumbai, India). Bradford reagent and 2,6,6-trinitrobenzenesulfonic acid (TNBS) were procured from BioRad (USA) and Sigma Aldrich respectively. Soy protein isolate and whey protein concentrate were prepared by in-house method; bovine serum albumin, casein (acc.to Hammarsten for biochemistry) were obtained from SRL. TRIS base, sodium phosphate (mono basic and dibasic) was purchased from HiMedia Ltd. All other chemicals used for experiments were of analytical grade.

\section{Analytical methods}

Estimation of protein content: Protein content of the samples was determined by Bradford's method. ${ }^{35} 0.8 \mathrm{ml}$ of diluted sample solution was mixed with $0.2 \mathrm{ml}$ of Bradford's reagent. The mixture was incubated for $5 \mathrm{~min}$ at room temperature and absorbance was measured at $595 \mathrm{~nm}$ on UV-spectrophotometer (Shimadzu UV 2100, Japan).

Protease activity assay: Activity of protease is estimated by its ability to hydrolyse a standard protein, thus for non-specific proteases casein digestion assay is used to measure hydrolytic activity. ${ }^{36}$ Casein solution $(2 \% \mathrm{w} / \mathrm{v})$ was prepared in phosphate buffer $(50 \mathrm{mM}, \mathrm{pH} 8.0)$. This solution was contacted with diluted soluble proteases or immobilized protease in 1:4ratio. Hydrolysis reaction was carried out at $50^{\circ} \mathrm{C}$ for $10 \mathrm{~min}$ which was then terminated by addition of $20 \%$ TCA solution (1:1 ratio). The mixture was centrifuged at $10000 \mathrm{rpm}$ for $5 \mathrm{~min}$. $2 \mathrm{ml}$ of supernatant was neutralized with $0.5 \mathrm{M} \mathrm{Na}_{2} \mathrm{CO}_{3}$, incubated at room temperature for $10 \mathrm{~min}$. $1 \mathrm{X}$ Folin \& ciocalteu's $(0.5 \mathrm{ml})$ was added after incubation, kept in dark conditions for 30min for colour development. Standard graph was plotted against different concentrations of standard Tyrosine $(80-6000 \mu \mathrm{M})$ with absorbance at $660 \mathrm{~nm}$. Colorimetric estimation was carried out at $660 \mathrm{~nm}$ using UV-spectrophotometer. Protease activity is calculated by Eq. 1.

$$
\mathrm{A}=\frac{\mathrm{mM} \text { Tyrosine released }{ }^{*} \mathrm{~V}^{*} \mathrm{D}}{\mathrm{t}^{*} \mathrm{E}}
$$

Where,

$\mathrm{A}=$ Protease activity, expressed as casein digesting units per minute per $\mathrm{ml}$

$\mathrm{V}=$ reaction volume (casein+enzyme), $\mathrm{ml}$

$\mathrm{D}=$ dilution factor for enzyme; $\mathrm{t}=$ reaction time, $\min$

$\mathrm{E}=$ amount of enzyme, $\mathrm{ml}$

Degree of hydrolysis: Degree of hydrolysis of protein substrate was analysed using protocol given by Adler-Nissen, with some modifications. ${ }^{37}$ Hydrolysed sample was diluted to $0.5 \mathrm{mg} / \mathrm{ml}$ protein content with $1 \%$ SDS (w/v) solution. $15 \mu$ diluted sample was transferred to microtiter plate to which $45 \mu \mathrm{l}$ phosphate buffer $(0.21 \mathrm{M}, \mathrm{pH} 8.2)$ was added. Further, $0.05 \%$ TNBS (v/v) solution was prepared in deionized water and $45 \mu 1$ was added in each well. Microtiter plate was covered with aluminium foil, incubated at $50^{\circ} \mathrm{C}$ for $60 \mathrm{~min}$. Reaction was terminated by addition of $90 \mu 10.1 \mathrm{NHCl}$ and colour intensity was determined using multiscan spectrum (Thermo scientific) at $340 \mathrm{~nm}$. Standard graph was plotted against different concentrations of standard Tyrosine $(200-2000 \mu \mathrm{M})$ with absorbance at $340 \mathrm{~nm}$. Degree of hydrolysis was estimated by Eq. $2 \& 3$.

$$
\mathrm{h}=\frac{\mathrm{mM} \text { Tyrosine released }{ }^{*} \mathrm{~V}}{\text { Amount of protein }(\mu \mathrm{g})}
$$

$$
\mathrm{DH}=\mathrm{h} / \mathrm{h}_{\text {tot }} * 100
$$

Where,

$\mathrm{DH}=$ degree of hydrolysis, $\%$

$\mathrm{V}=$ volume of hydrolysed protein, $\mu 1$

$\mathrm{h}=$ number of equivalents of peptide bonds hydrolysed, meq/g of protein

$\mathrm{h}_{\text {tot }}=$ total amount of peptide bonds. 
Gel permeation chromatography: Molecular weight of peptides and proteins was analyzed by using gel permeation chromatography. A column Agilent BIOSEC-3 (pore size $150 \mathrm{~A}^{\circ}$ ) was used for determining peptide distribution in protein hydrolysate. Mobile phase consisted of phosphate buffer $(150 \mathrm{nM}, \mathrm{pH} 7.0)$ which was filtered and degassed prior to use. All samples were diluted to $1 \mathrm{mg} / \mathrm{ml}$ protein concentration and filtered through $0.2 \mu$ filter. $20 \mu \mathrm{l}$ of sample was eluted with phosphate buffer (isocratic mode) at flow rate of $0.5 \mathrm{ml} /$ min and $30^{\circ} \mathrm{C}$ column temperature. Elution profile was determined at $215 \mathrm{~nm}$ with UV detector. Column was calibrated using BioRad protein marker kit, a calibration curve was plotted with $\log$ (molecular weight) vs elution volume and used for determining molecular weight of peptides.

MS analysis: Soy protein hydrolysate was characterized with Nanochip (ProteinID chip-43, 300A, C18-43mm column) and MS 6520 (Accurate mass QTOF-LC/MS, Agilent Technologies) i.e. using high resolution methodology. Sample was dissolved in $0.1 \%$ formic acid in MS grade water; cleaned up using C-18 based purification and subsequent elution. Gradient mobile phase was used composed of $0.1 \%$ formic acid in water (A) and $0.1 \%$ formic acid in $90 \%$ ACN (B) with run time of $60 \mathrm{mins}$ at $0.3 \mu \mathrm{l} / \mathrm{min}$ flow rate. MS data was analysed with spectrum mill' software (Agilent technologies).

\section{Experimental methods}

Screening of endo-proteases: Different endo-proteases were tested for their hydrolytic activity using casein digestion assay. All enzymes $6 \mathrm{~L}, 7 \mathrm{~L}, 15 \mathrm{~L}, 26 \mathrm{~L}$ and $89 \mathrm{~L}$ were diluted using deionized water and analysed for protein content using Bradford's assay; further their protein content and respective proteolytic activities were compared in order to determine efficient protease. Stability of $89 \mathrm{~L}$ was determined in presence of Tris buffer $(50 \mathrm{mM}, \mathrm{pH} 9.0)$ after $2 \mathrm{hrs}$ incubation at $25^{\circ} \mathrm{C}$; final protease activity was analysed using casein assay and compared with initial activity to determine loss of hydrolytic activity in $2 \mathrm{hrs}$. Further, half-life of soluble 89L was determined by incubating enzyme solution under laboratory conditions $\left(\right.$ at $25^{\circ} \mathrm{C}$ ) and corresponding loss in activity was analysed by casein assay.

Immobilization of 89L: Diaion CR20 was washed in methanol followed by equilibration in phosphate buffer and degassing; this cationic resin was activated with glutaraldehyde solution. A modified protocol with $2 \% \mathrm{v} / \mathrm{v}$ glutaraldehyde, was used for activation of CR20 and mixed with diluted enzyme solution at room temperature. ${ }^{38}$ After immobilization, buffer washes were given to release unbound enzyme; further immobilized enzyme was assessed for hydrolytic activity by casein assay.

Optimization of immobilized parameters: Equilibrated CR20 resin was activated with glutaraldehyde solution for different time periods (4-20hrs) to determine optimum activation time period for maximum enzyme adsorption. After determining activation time, optimization of glutaraldehyde concentration $(0.25-2 \% \mathrm{v} / \mathrm{v})$ was carried out at $25^{\circ} \mathrm{C}$, using phosphate buffer $(50 \mathrm{mM}, \mathrm{pH} 7)$ with resin to solution ratio of 1:2. Further binding capacity of activated resin was determined at optimized glutaraldehyde concentration with enzyme loading in the range of $0.5-30 \mathrm{mg}$ per $\mathrm{ml}$ of resin. Enzyme loading was optimized in the range of $0.5-4 \mathrm{mg} / \mathrm{ml}$ of resin at 1:1 immobilization ratio (volume of enzyme solution to mass of resin) and optimum coupling time was determined $(0.5-6 \mathrm{hrs})$ at $25^{\circ} \mathrm{C}$ to obtain immobilized preparation with highest hydrolytic activity.
Characterization and stability studies: Immobilized 89L was analyzed for its catalytic activity in $\mathrm{pH}$ range 6.5 to 11 ; (phosphate buffer, Tris buffer and carbonate buffer, $50 \mathrm{mM}$ ) and temperature $30-70^{\circ} \mathrm{C}$, which was compared with activity profile of soluble $89 \mathrm{~L}$ to understand enhancement in tolerance of enzyme after immobilization. Similarly, immobilized 89L was studied for its storage and operational stability. Storage stability was determined by estimating hydrolytic activity of enzyme intermittently during prolonged cold storage at $4^{\circ} \mathrm{C}$ in Tris buffer. On the other hand, operational stability was analyzed by hydrolysis of bovine serum albumin $(25 \mathrm{mg} / \mathrm{ml})$ in Tris buffer $\left(50 \mathrm{mM}, \mathrm{pH}\right.$ 9) at $2 \mathrm{ml} / \mathrm{min}$ feed rate in jacketed column $\left(50^{\circ} \mathrm{C}\right)$ packed with $10 \mathrm{ml}$ of immobilized enzyme.

Hydrolysis of proteins with immobilized 89L: Soy proteins, whey protein concentrate and BSA were hydrolyzed in batch mode using immobilized 89L. All proteins were hydrolyzed with mixing immobilized $89 \mathrm{~L}$ in $1: 10$ ratio $(\mathrm{m} / \mathrm{v})$ at $50^{\circ} \mathrm{C}$ in shaker $(180 \mathrm{rpm})$ for $6 \mathrm{hrs}$. Samples were analyzed for degree of hydrolysis with TNBS assay

Peptide profiling of protein hydrolysates: Initial hydrolysis study was carried out with single pure protein substrate i.e. BSA using immobilized 89L. Different concentrations of BSA $1-150 \mathrm{mg} / \mathrm{ml}$ prepared in Tris buffer $(50 \mathrm{mM}, \mathrm{pH} 9)$ were tested for protein digestion with enzyme substrate ratio of $1: 10(\mathrm{~m} / \mathrm{v})$ at $50^{\circ} \mathrm{C}$ for $200 \mathrm{~min}$. Use of single protein substrate was suitable to check change in pattern of hydrolysis during course of reaction progress. TNBS assay was used to determine degree of hydrolysis. After establishing proteolytic pattern for single protein substrate, immobilized protease was utilized to hydrolyze natural proteins i.e. soy protein isolate which comprised of mixture of proteins. Soy proteins were dissolved in Tris buffer $(50 \mathrm{mM}, \mathrm{pH} 9)$ at concentration of $1-50 \mathrm{mg} / \mathrm{ml}$ concentration and subjected to hydrolysis with $1: 10 \mathrm{~m} / \mathrm{v}$ enzyme substrate ratio at $50^{\circ} \mathrm{C}$ for 200min. Further, samples of BSA and soy protein hydrolysates varying in degree of hydrolysis, were analyzed using Gel Permeation Chromatography for distribution of peptides. The GPC profiles were used to study formation of low molecular weight peptides with respect to degree of hydrolysis which could be advantageous in determining optimum parameters for protein hydrolysis to yield peptides with desired molecular weights.

Effect of enzyme substrate ratio on protein hydrolysis: Soy protein hydrolysis was studied at different enzyme substrate (E-S) ratio in batch mode, $25 \mathrm{mg} / \mathrm{ml}$ of protein solution was subjected to various enzyme loading namely $1: 2,1: 5$ and $1: 10 \mathrm{~m} / \mathrm{v}$. Proteolysis was carried out at $50^{\circ} \mathrm{C}$ for $6 \mathrm{hrs}$, change in degree of hydrolysis was determined after specific time intervals and compared to evaluate effect of enzyme loading on progress of reaction.

Packed bed column hydrolysis: Immobilized 89L was packed in jacketed column (with $1 \mathrm{~cm} \mathrm{ID),} \mathrm{soy} \mathrm{protein} \mathrm{solution}(25 \mathrm{mg} / \mathrm{ml}$ ) prepared in Tris buffer $(50 \mathrm{mM}, \mathrm{pH} 9)$ was fed from bottom of the column, hydrolysis was carried out at varied residence time and degree of hydrolysis was determined with TNBS assay. Temperature of column was maintained at $50^{\circ} \mathrm{C}$ with water bath. Degree of hydrolysis was monitored for 15 column volumes to confirm uniformity of hydrolysis after each cycle using TNBS assay.

\section{Result and discussion}

\section{Screening of commercial endo-proteases}

Endo-proteases are able to cleave polypeptide chain internally to produce peptide fragments of varying molecular size, unlike exo- 
proteases which cut at polypeptide ends to release amino acids as major products. ${ }^{8}$ Proteases fall into different categories like acidic, alkaline and neutral (based on optimum working $\mathrm{pH}$ ). In case of endo-proteases; their cleavage site and hydrolytic activity are key factors which govern peptide formation, ${ }^{39}$ higher hydrolytic activity is preferred as it improves peptide yield. Commercial endo-proteases $6 \mathrm{~L}, 7 \mathrm{~L}, 15 \mathrm{~L}, 26 \mathrm{~L}$ and $89 \mathrm{~L}$ were analysed for their protein content at different $\mathrm{pH}$ conditions; herein we report comparative activity of these protease at $\mathrm{pH} 9$ (Figure 1). Since most of the proteins are soluble under alkaline conditions, use of alkaline protease proves to be desirable option. Under alkaline condition $\left(\mathrm{pH} 8\right.$ at $\left.50^{\circ} \mathrm{C}\right) ; 6 \mathrm{~L}, 7 \mathrm{~L}$ and $89 \mathrm{~L}$ exhibited catalytic activity while $15 \mathrm{~L}$ and $26 \mathrm{~L}$ were active at acidic $\mathrm{pH}$ range. $6 \mathrm{~L}, 7 \mathrm{~L}$ and $89 \mathrm{~L}$ had specific activity of 30137 , 13319 and $33514 \mathrm{CDU} / \mathrm{mg}$ of protein respectively. 89L was selected for controlled protein hydrolysis, based on its higher hydrolytic activity. Generally, protein hydrolysis process have reaction time about 5-6 hrs and soluble proteases tend to have lower shelf life due to their autocatalytic activity. ${ }^{25,28}$ Therefore, in spite of higher catalytic activity, stability of protease in a reaction medium governs its usability for hydrolysate production and determination of protease stability becomes necessary prior to its use in peptide generation.

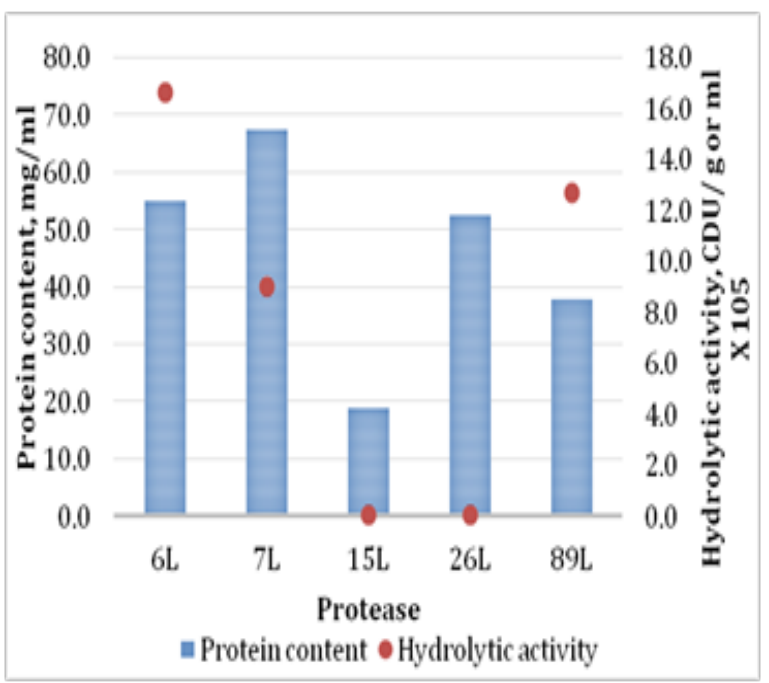

Figure I Screening of endo-proteases.

Study was carried out to check stability of soluble $89 \mathrm{~L}$ at different concentrations $(0.5-4 \mathrm{mg} / \mathrm{ml})$ at $\mathrm{pH}$ 9. It was observed that, low protease concentrations showed slight loss in hydrolytic activity while steep increase in loss of hydrolytic activity was seen at high concentrations after $2 \mathrm{hrs}$; that can be attributed to increased autolytic behaviour of protease (Figure 2). Proteases like 89L i.e. subtilisin reported to have shorter shelf life about $86 \mathrm{mins}^{40}$ and are more prone to autolysis. Therefore, change in proteolytic activity for current protease preparation was analyzed for $10 \mathrm{hrs}$ in presence of buffer under laboratory condition $\left(25^{\circ} \mathrm{C}\right)$. Rapid loss in activity was observed and half of soluble $89 \mathrm{~L}$ was found to be $90 \mathrm{~min}$; this study demonstrated unstable nature of soluble 89L (Figure 3). Thus, improving stability of protease with implementation of immobilization techniques becomes necessary prior to its usage for hydrolysate/peptide production. ${ }^{28,29}$ Previously, protease immobilization studies have been carried out using glutaraldehyde which showed increased operational and storage stability as compared to its soluble form. ${ }^{49}$ Hence, glutaraldehyde coupling was selected for increasing stability of 89L.

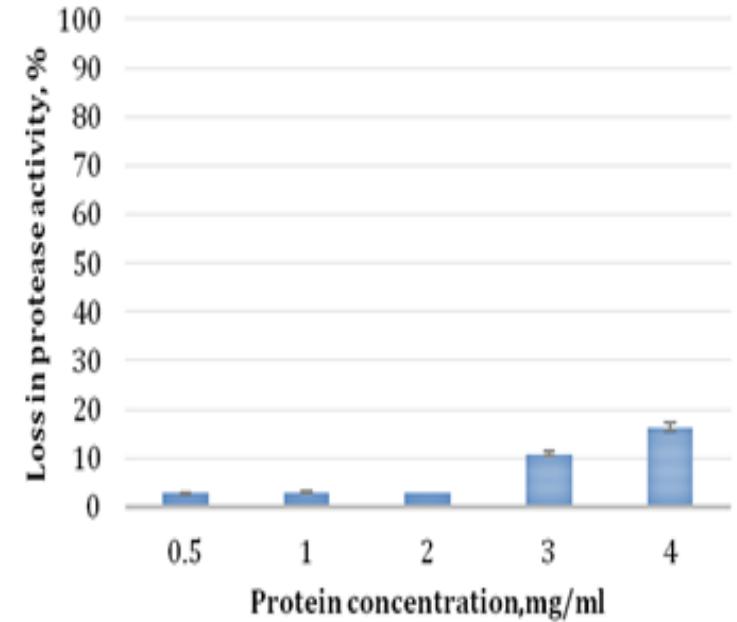

Figure 2 Stability of soluble $89 \mathrm{~L}$ in buffer.

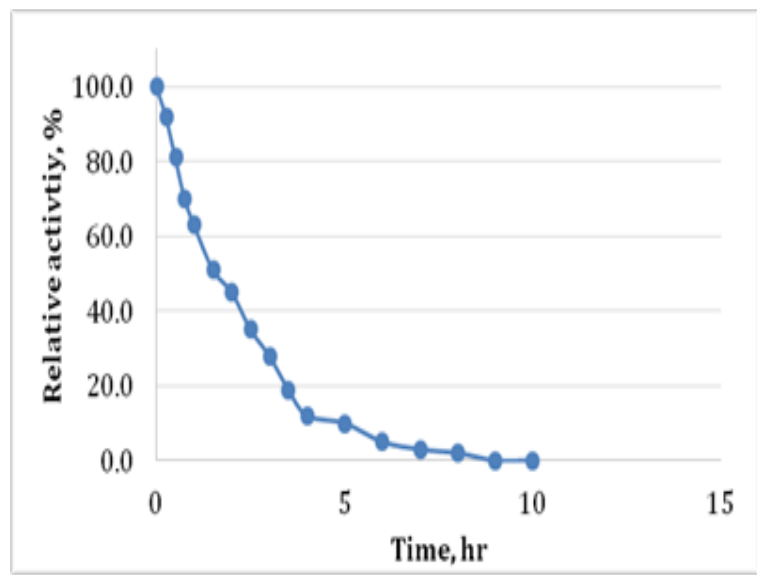

Figure 3 Half-life of soluble 89L.

\section{Immobilization of 89L}

Resin activation for glutaraldehyde coupling: Glutaraldehyde is a bifunctional reagent which irreversibly binds to amine groups and can act as anchoring molecule between two entities (Figure 4). For immobilization, initially support matrix with free amine groups is coated with glutaraldehyde which is then combined with enzyme. ${ }^{29}$ In earlier work, immobilization of protease was optimized at $2 \%(\mathrm{v} / \mathrm{v})$ glutaraldehyde concentration, $4 \mathrm{mg} / \mathrm{ml}$ enzyme loading and $4 \mathrm{hrs}$ of coupling time. This preparation had hydrolytic activity of $1397 \mathrm{CDU} / \mathrm{ml}$ which was stable for 20 days ${ }^{49}$ thus glutaraldehyde coupling was found to be suitable for protease stabilization. Therefore, optimization studies were carried out for current protease preparation. It is necessary to activate all side chains of support resin which increases surface area for enzyme binding to obtain high immobilization efficiency. ${ }^{30}$ The CR20 resin was activated with $2 \%$ glutaraldehyde solution with $1: 1$ immobilization ratio at $25^{\circ} \mathrm{C}$ for $4-20 \mathrm{hrs}$ before contacting with enzyme. It was observed that highest enzyme binding (59\%) was obtained after 16 hrs activation with $1800 \mathrm{CDU} / \mathrm{mg}$ of protein specific activity. Hence, activation time of 16 hrs was used for further experiments; these results coincide with the experiments carried out to immobilize procerain $\mathrm{B}$ which required $20 \mathrm{hrs}$ of activation time..$^{33}$

Variation of glutaraldehyde concentration for activation: Along with binding efficiency of enzyme to support matrix, its hydrolytic 
activity after immobilization is an important parameter. Glutaraldehyde concentration which is used for activation would influence both enzyme binding and activity. At low glutaraldehyde concentration, all amine groups of support matrix remain un-utilized; while high glutaraldehyde concentrations lead to multi point attachment of enzyme. Suitable glutaraldehyde concentration varies with protease being used $1 \%$ for mungbean thiol protease, ${ }^{32} 5 \%$ for acylase ${ }^{41}$ while $2 \%$ for papain. ${ }^{42}$ Hence, there is need to determine suitable glutaraldehyde concentration, where, higher hydrolytic activity is obtained with minimal enzyme load. Different glutaraldehyde concentrations ranging from $0.25-2 \% \mathrm{w} / \mathrm{v}$ were tested for immobilization of $89 \mathrm{~L}$; resin activation was carried out in phosphate buffer $(50 \mathrm{mM}, \mathrm{pH} 7)$ with immobilization ratio of $1: 1$, enzyme loading $4 \mathrm{mg} / \mathrm{ml}$ of resin at $25^{\circ} \mathrm{C}$ for 16 hrs. It was observed that, enzyme binding increased linearly with glutaraldehyde concentration, but proteolytic activity of immobilized preparation showed initial increase followed by a slight decrease at higher concentrations (Figure 5), similar trend was observed when acylase was immobilized at various glutaraldehyde concentrations. ${ }^{41}$ At $1 \%$ glutaraldehyde concentration, highest proteolytic activity was observed without compromising enzyme binding. The immobilized preparation showed $6429 \mathrm{CDU} / \mathrm{ml}$ hydrolytic activity with specific activity of $3257 \mathrm{CDU} / \mathrm{mg}$ of protein.

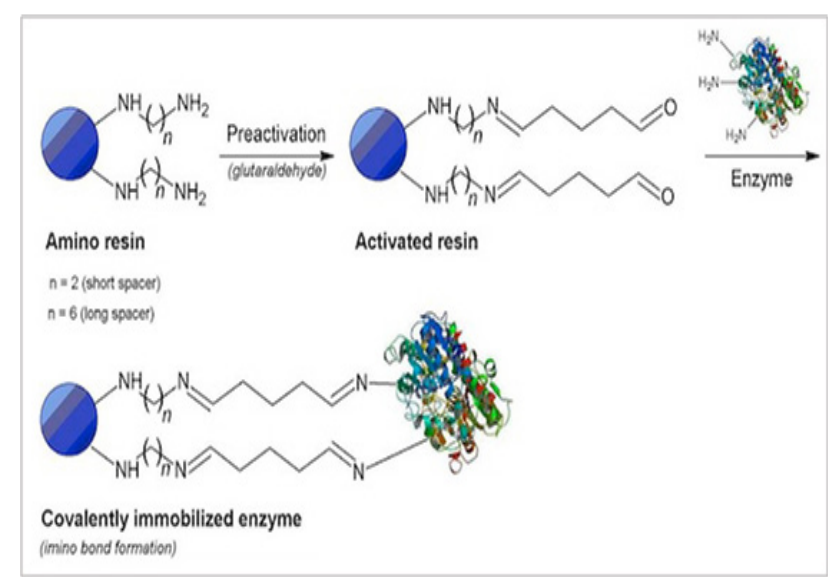

Figure 4 Chemistry for glutaraldehyde mediated immobilization.

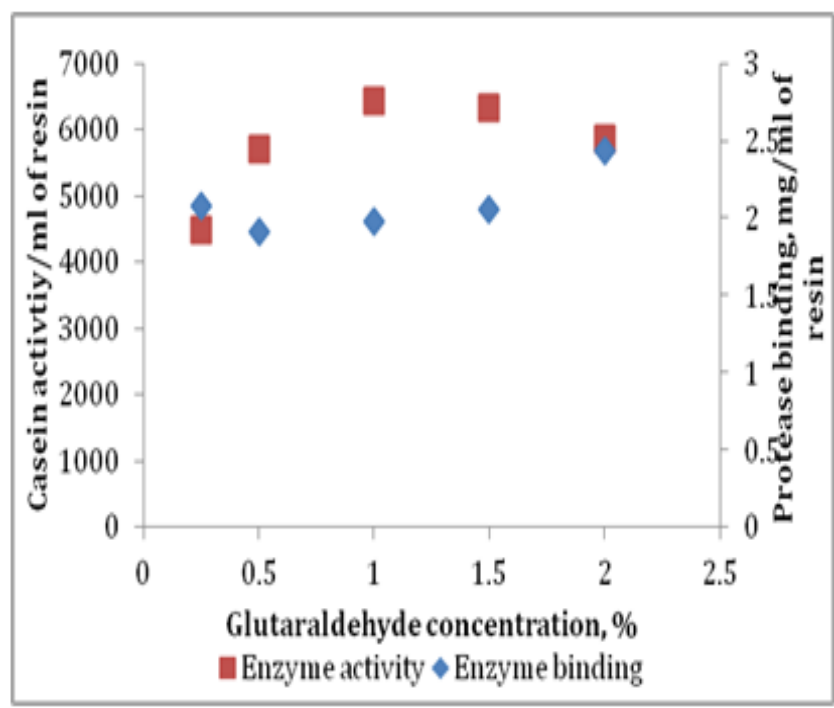

Figure 5 Optimization of glutaraldehyde concentration for resin activation.
Binding capacity of activated CR20 for 89L: Prior to enzyme loading optimization, there is need to assess maximum binding capacity of activated resin at $1 \%$ glutaraldehyde concentration. Study of enzyme binding at different concentrations helps to understand its binding pattern. ${ }^{43}$ Similarly, binding capacity of activated CR20 was determined in the range of $0.5-30 \mathrm{mg}$ enzyme load per $\mathrm{ml}$ of resin (Figure 6). Plot of $1 / \mathrm{c}$ (concentration) vs $1 / \mathrm{q}^{*}$ (bound enzyme) gave maximum binding capacity of $6 \mathrm{mg} / \mathrm{ml}$ for $89 \mathrm{~L}$ on activated CR20 resin. However, maximum binding capacity dose not correlate with highest catalytic activity after immobilization, which can be attributed to multilayer enzyme binding or crowding of enzyme molecules. Hence, effect of enzyme loading needs to be studied with respect to catalytic activity post-immobilization.

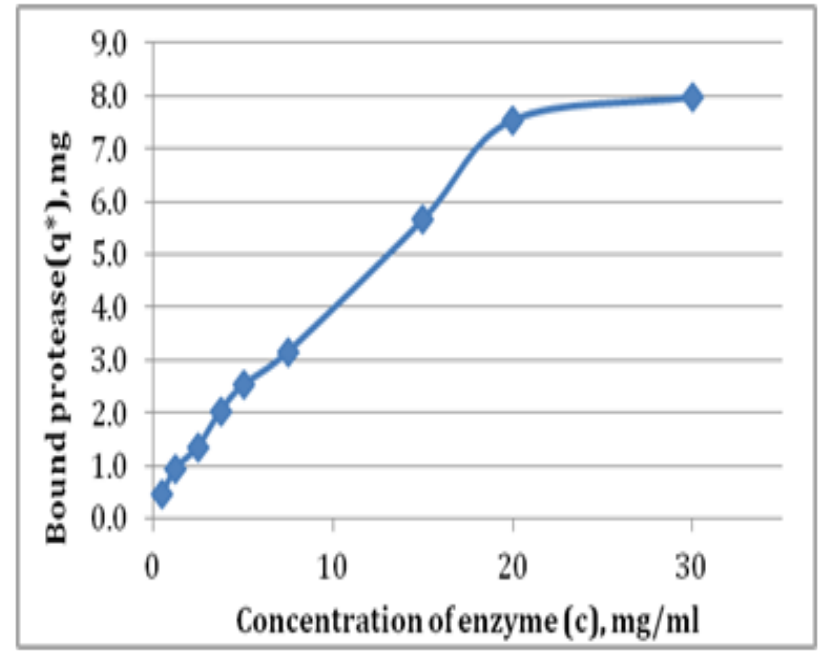

Figure 6 Enzyme binding to activated CR20.

Effect of enzyme loading: Enzyme concentrations $(0.5-4 \mathrm{mg} / \mathrm{ml})$ were used for immobilization study with $1 \%$ glutaraldehyde activated CR20. Figure 7 shows that, immobilized enzyme activity increased linearly with initial enzyme load; $4 \mathrm{mg} / \mathrm{ml}$ of $89 \mathrm{~L}$ loading gave highest immobilized activity of $9260 \mathrm{CDU} / \mathrm{ml}$ with specific activity being $3825 \mathrm{CDU} / \mathrm{mg}$ of protein. Immobilized preparation obtained by optimized protocol was further evaluated for improved $\mathrm{pH}$, temperature tolerance with storage and operational stability. After optimizing enzyme concentration, study was carried out to estimate minimal time required for coupling of activated resin and enzyme solution. As glutaraldehyde is a bifunctional reagent, its prolonged exposure may cause cross-linking of enzyme molecules instead of binding to support matrix. ${ }^{30}$ Immobilization of $89 \mathrm{~L}(4 \mathrm{mg} / \mathrm{ml})$ on activated CR20 was performed for $6 \mathrm{hrs}$, aliquots were analysed for protein content to determine rate of enzyme binding on resin. Enzyme immobilization exhibited gradual increase in stepwise manner with rapid biding during 30-45mins. Figure 8 shows minimum time required for immobilization of $89 \mathrm{~L}$ is $120 \mathrm{~min}$ i.e. $2 \mathrm{hrs}$; beyond which there is no significant improvement in protein binding.

\section{Characterization of immobilized protease}

Optimum pH and temperature: Casein digesting activity of immobilized preparation was analyzed at varying $\mathrm{pH}(6.5-11)$ and temperatures $\left(30-70^{\circ} \mathrm{C}\right)$ to determine optimum working conditions for $89 \mathrm{~L}$ after immobilization. Figure $9 \& 10$ show $\mathrm{pH}$ and temperature profiles of immobilized 89L compared with soluble 89L. Both profiles indicate improved tolerance of $89 \mathrm{~L}$ towards $\mathrm{pH}$ and temperature condi- 
tions after immobilization. Soluble 89L had optimum activity at $\mathrm{pH} 9$ while immobilized preparation could hydrolyze proteins in range of 9-10 pH. Immobilized serine protease was found to tolerate temperature range of $50-70^{\circ} \mathrm{C}$ but soluble counterpart exhibited rapid loss in activity beyond $50^{\circ} \mathrm{C}$

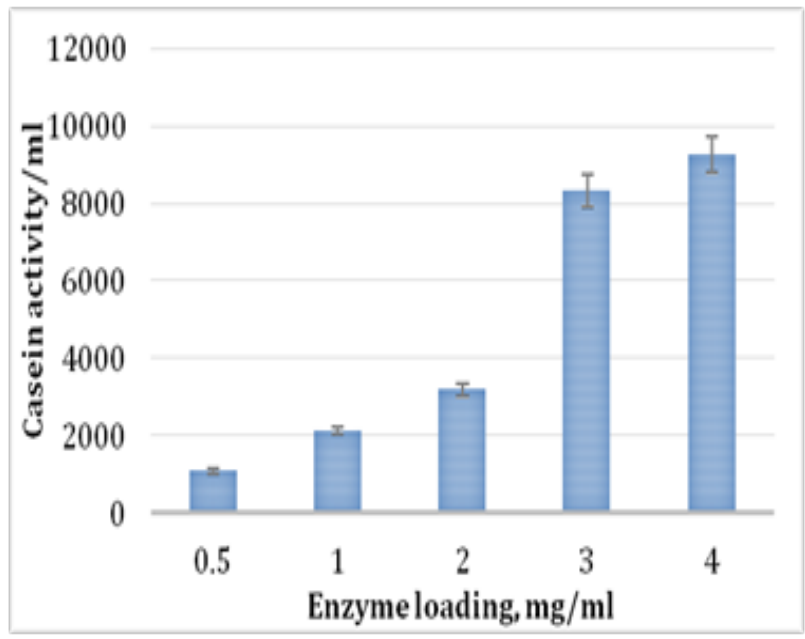

Figure 7 Optimization of enzyme loading.

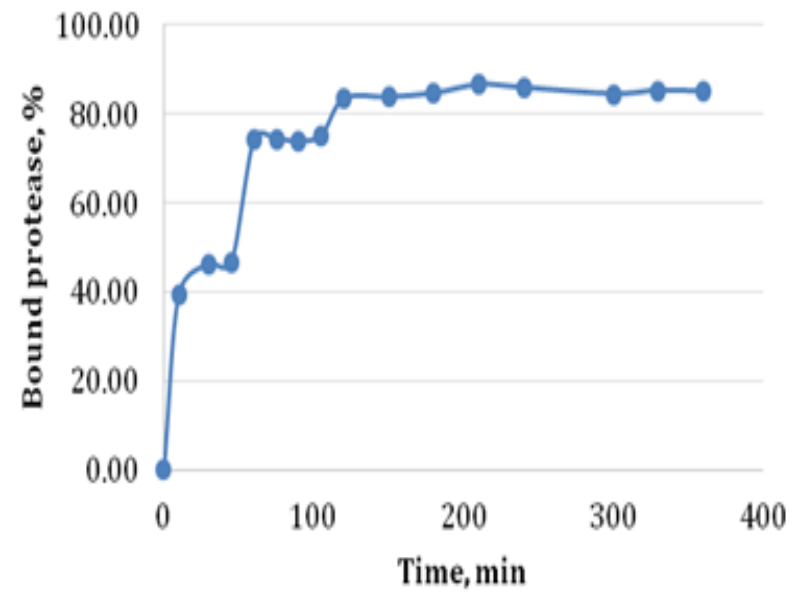

Figure 8 Determination of coupling time for immobilization.

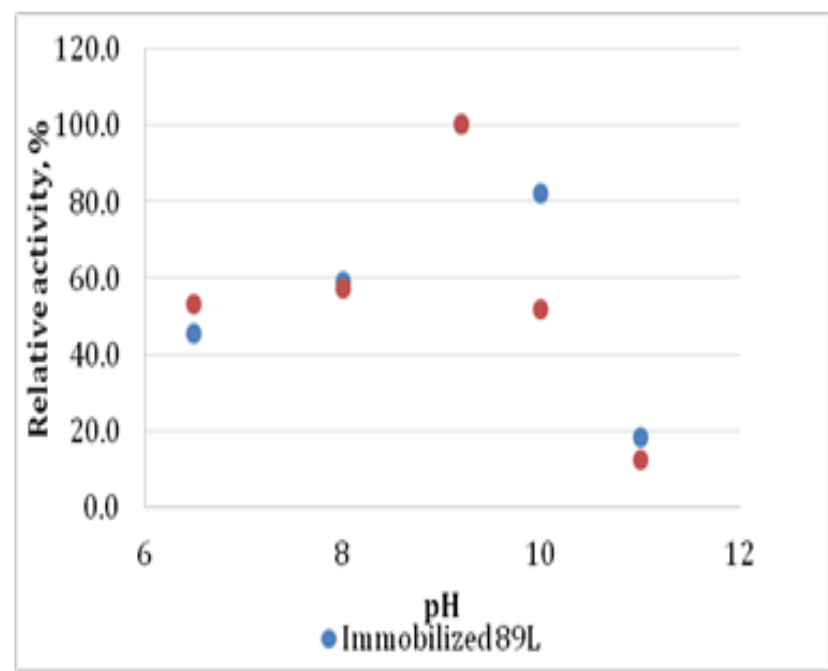

Figure 9 Optimum pH for soluble and immobilized protease.

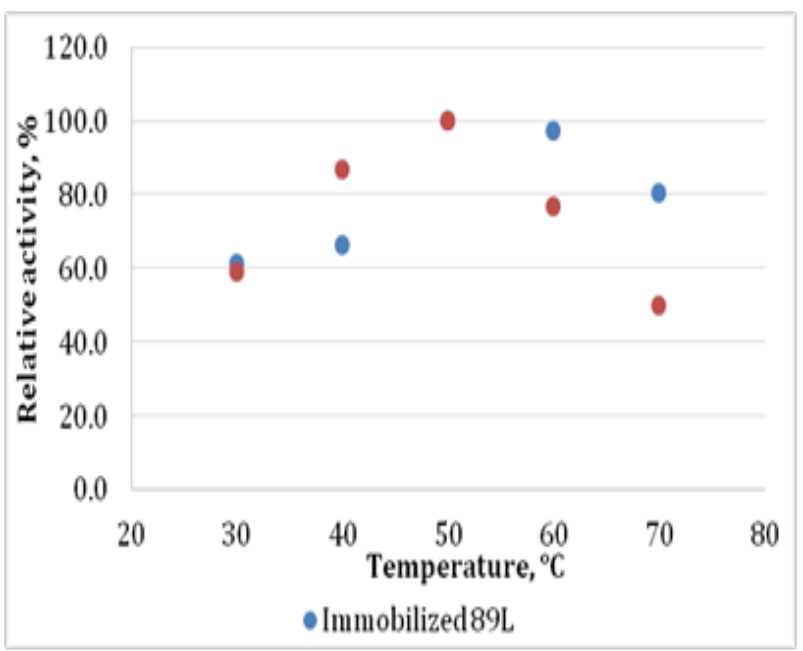

Figure 10 Optimum temperature for soluble and immobilized protease.

Stability studies: Operational stability of immobilized preparation was estimated by determining its hydrolytic activity in a packed bed column after each cycle. It was observed that immobilized serine protease gave constant degree of hydrolysis of substrate (bovine serum albumin solution) at $50^{\circ} \mathrm{C}$ for 10 cycles beyond which there was slight decrease in enzymatic activity. Immobilized and soluble 89L were stored in cold conditions, during this period their activity profiles were recorded for 10 days at specific time intervals. Results indicated that the immobilized preparation was stable up to 2 days with $60-70 \%$ retained activity at $4^{\circ} \mathrm{C}$. Singh et al. reported loss of $50 \%$ proteolytic activity of immobilized procerain after $10^{\text {th }}$ cycle, ${ }^{33}$ bacterial protease immobilized on calcium alginate beads retained $65 \%$ activity after 2 days. ${ }^{44}$ Thus, immobilized $89 \mathrm{~L}$ showed good storage stability and can be repeatedly utilized for controlled protein hydrolysis.

\section{Hydrolysis of proteins with immobilized 89L}

Initial study was carried out to check efficiency of immobilized 89L towards hydrolysis of different types of proteins. Soy protein isolate, whey protein concentrate, bovine serum albumin were hydrolysed in batch mode by immobilized 89L. Enzyme and substrate solutions prepared in Tris buffer $(50 \mathrm{mM}, \mathrm{pH} 9)$ were mixed in $1: 10(\mathrm{v} / \mathrm{v})$ ratio and hydrolysis was carried out at $50^{\circ} \mathrm{C}$ in shaker (180rpm) for $6 \mathrm{hrs}$. Rapid increase in hydrolysis was observed during initial $2 \mathrm{hrs}$ beyond which reaction progressed at much slower rate. The hydrolysis profiles showed that soy proteins being high in molecular weight undergo lesser hydrolysis as compared to whey proteins and bovine serum albumin which are smaller in size (Figure 11). Soy proteins also contain trace amount of protease inhibitors which may also cause low protein hydrolysis. ${ }^{45}$ These results were comparable to the soy protein hydrolysis carried out by flavouzyme which obtained 15\% DH after 6 hrs. ${ }^{14}$ Alcalase immobilized on magnetic nano particles hydrolysed soy proteins up to $18 \% \mathrm{DH}^{46}$

Peptide profiling of protein hydrolysates: Studies were carried out to understand action of serine protease; whether it favours generation of high or low molecular weight peptides and correlating degree of hydrolysis with peptide molecular weights produced thereof. Bovine serum albumin was used as substrate; different concentrations ranging from $1-150 \mathrm{mg} / \mathrm{ml}$ dissolved in Tris buffer $(50 \mathrm{mM}, \mathrm{pH} 9)$ were hydrolysed with enzyme substrate ratio of 1 : $10(\mathrm{~m} / \mathrm{v})$ at $50^{\circ} \mathrm{C}$ for $200 \mathrm{~min}$. Proteolysis rate was higher at lower substrate concentrations while extent of hydrolysis declined at high 
concentrations due to saturation of enzyme preparation (Figure 12). Gel permeation chromatography analysis of BSA hydrolysates with varying $\mathrm{DH} \%$ confirmed formation of low molecular weight peptides (less than $10 \mathrm{kDa}$; typically below $1 \mathrm{kDa}$ ) after $3 \mathrm{hrs}$ incubation (Table 1). Substrate was initially hydrolysed into larger peptide fragments that were gradually converted to smaller peptides with progress of reaction time. Similar experiments were carried out with soy protein isolate. The substrate concentration used for hydrolysis was $1-50 \mathrm{mg} /$ $\mathrm{ml}$. The degree of hydrolysis was not linear with respect to substrate loading. As soy protein isolate is comprised of proteins like glycinin, conglycinin, lipoxygenase etc. each protein is hydrolysed to different extent and combined effect of this individual protein hydrolysis is not observed as overall increase in degree of hydrolysis (Figure 13). However conversion of all these proteins into short peptides was confirmed with gel permeation chromatography analysis.

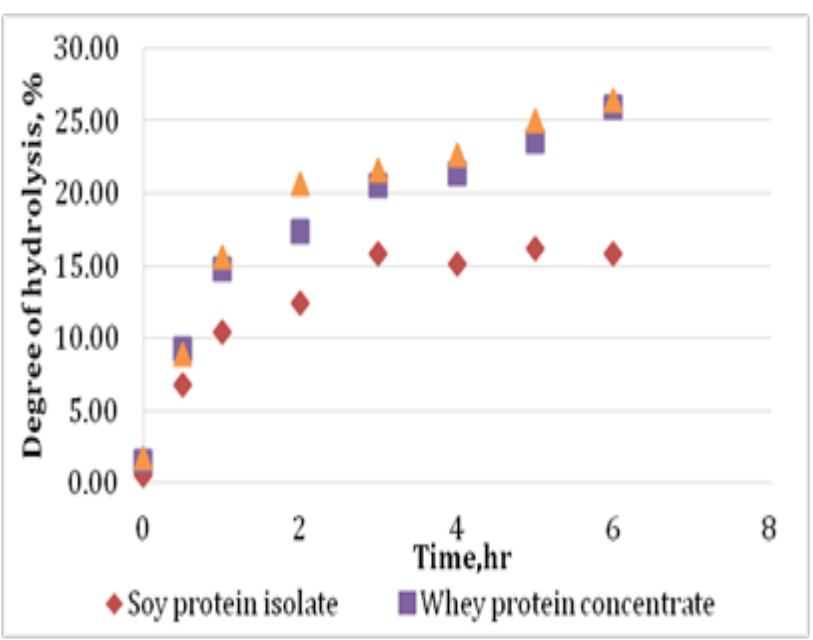

Figure II Hydrolysis of proteins with immobilized 89L.

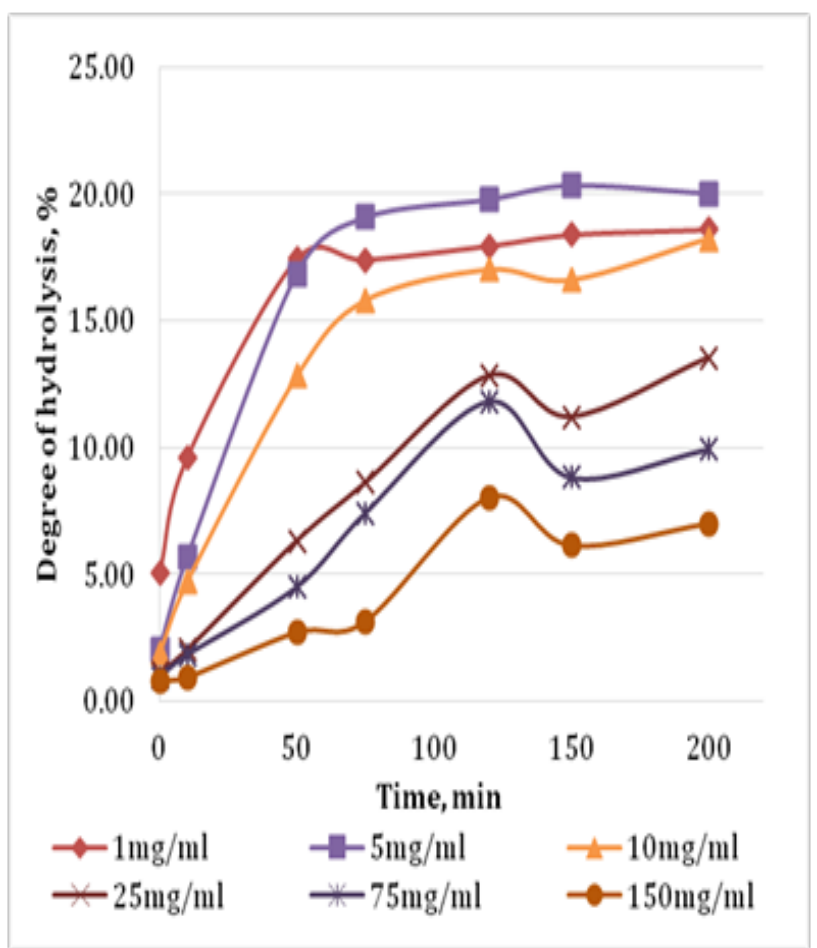

Figure 12 BSA hydrolysis at different substrate concentrations.

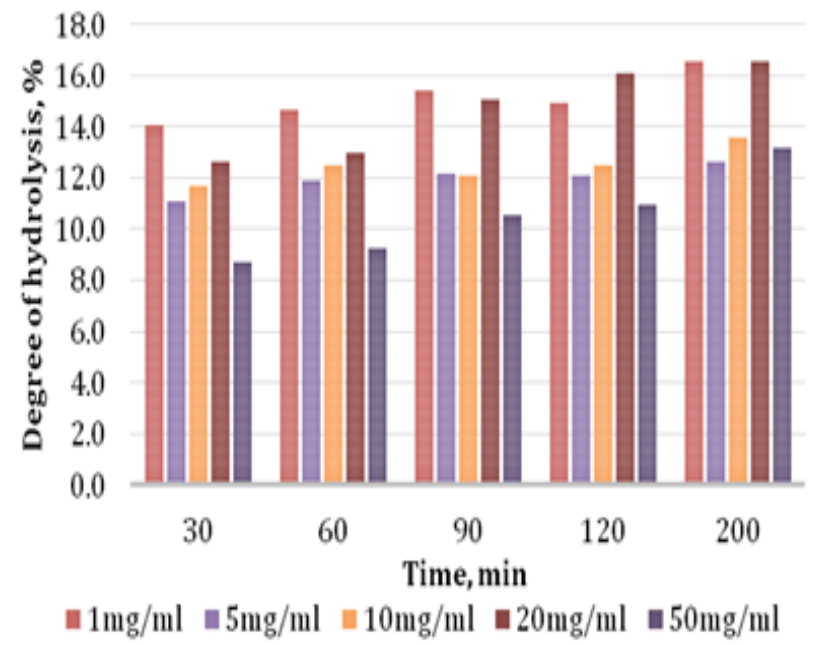

Figure 13 Soy protein hydrolysis at different substrate concentrations.

Table I Peptide distribution in BSA hydrolysates

\begin{tabular}{|c|c|c|c|c|c|c|}
\hline \multirow{2}{*}{ MW (kDa) } & \multicolumn{6}{|c|}{ \% Distribution of peptides } \\
\hline & BSA & $0.25 \mathrm{hr}$ & $0.5 \mathrm{hr}$ & Ihr & $3 h r$ & $5 \mathrm{hr}$ \\
\hline 65 to 67 & 100 & 1.86 & 0.74 & 0.45 & 0.4 & 0.48 \\
\hline 50 to 65 & & 1.74 & 1.44 & 1.31 & 1.33 & 0.98 \\
\hline 20 to 50 & & 15.29 & & & & \\
\hline 10 to 20 & & 10.18 & 4.8 & 2.43 & & \\
\hline I to 10 & & 45.3 & 49.06 & 40.19 & 44.26 & 45.86 \\
\hline$<1$ & & 25.65 & 43.97 & 55.61 & 53.98 & 52.68 \\
\hline $\begin{array}{l}\text { Degree of } \\
\text { hydrolysis, \% }\end{array}$ & & 1.71 & 7.28 & 15.59 & 21.62 & 25.01 \\
\hline
\end{tabular}

Hydrolysates aliquoted at different time intervals exhibited varied degree of hydrolysis which was correlated with formation of small molecular weight peptides using gel permeation chromatography. Variation in contact time reflected change in extent of protein hydrolysis; larger polypeptides $\geq 200 \mathrm{kDa}$ were converted into short peptides $10-25 \mathrm{kDa}(12 \%)$ and $\leq 1 \mathrm{kDa}(81 \%)$ after $5 \mathrm{hrs}$ incubation (Table 2). These results suggested tailoring of protein hydrolysis can be achieved by controlling contact time between protease and substrates. Controlled protein hydrolysis is also reported for whole whey proteins with trypsin that produced peptides in the range of $7.5-8 \mathrm{kDa}$ and $4-4.5 \mathrm{kDa}$; whereas fungal protease yielded peptides with molecular weight of $7-7.5 \mathrm{kDa}$ depending upon enzyme specificity. ${ }^{6}$ It can be observed that, there is linear correlation between degree of hydrolysis and formation of smaller peptides with progress of reaction. Use of immobilized protease offer an advantage in separating the hydrolysed peptide solution and enzyme; thereby regulating extent of hydrolysis of protein substrate. Thus, specific molecular weight peptides with defined bioactivity can be produced easily by employing immobilized protease. Optimized substrate concentration and reaction time greatly helps in obtaining peptides with desired molecular weight.

Effect of enzyme substrate ratio on protein hydrolysis: Enzyme substrate ratio also contributes to overall hydrolysis of proteins. Hence soy protein hydrolysis reaction was studied under different E-S ratios $(1: 10,1: 5$ and $1: 2 \mathrm{~m} / \mathrm{v})$ in batch mode where mass transfer is not limiting the progress of reaction. Figure 14 depicts that hydrolysis of 
proteins was directly proportional to E-S ratio i.e. higher E-S $1: 10 \mathrm{~m} / \mathrm{v}$ showed highest hydrolysis up to $14 \% \mathrm{DH}$. After understanding the catalytic action of immobilized protease, batch mode of hydrolysis was selected for production of soy protein hydrolysate containing low molecular weight peptides. Optimum conditions; E-S ratio of $1: 10 \mathrm{v} / \mathrm{v}$, $25 \mathrm{mg} / \mathrm{ml} \mathrm{SPI}$ concentration and batch mode hydrolysis at $50^{\circ} \mathrm{C}$ for $5 \mathrm{hrs}$ produced protein hydrolysate with degree of hydrolysis $14.5 \%$. GPC analysis revealed abundance of low molecular weight peptides $(<1 \mathrm{kDa})$ in hydrolysate. However batch operation is longer process and necessitates development of continuous process for protein hydrolysis.

Table 2 Peptide distribution in soy protein hydrolysates

\begin{tabular}{lllllll}
\hline \multirow{2}{*}{ MW (kDa) } & \multicolumn{7}{l}{ \% Distribution of peptides } \\
\cline { 2 - 7 } & $\mathbf{S P I}$ & $\mathbf{0 . 2 5} \mathbf{h r}$ & $\mathbf{0 . 5} \mathbf{h r}$ & $\mathbf{I h r}$ & $\mathbf{3 h r}$ & $\mathbf{5 h r}$ \\
\hline$>200$ & 36.91 & 30.87 & 0.34 & & & \\
75 to 200 & 16.67 & 15.32 & 1.65 & 1.22 & 0.83 & 0.46 \\
50 to 75 & 15.25 & 22.11 & & & & \\
25 to 50 & & & 7.36 & 3.49 & 3.26 & 1.95 \\
10 to 25 & 14.38 & 16.02 & 9.77 & 10.94 & 12.79 & 11.96 \\
I to 10 & & & 15.04 & 16.77 & 4.47 & 4 \\
$<1$ & 16.79 & 15.67 & 65.86 & 67.59 & 78.65 & 81.63 \\
$\begin{array}{l}\text { Degree of } \\
\text { hydrolysis, \% }\end{array}$ & & 8.69 & 11.24 & 11.17 & 13.67 & 13.93 \\
\hline
\end{tabular}

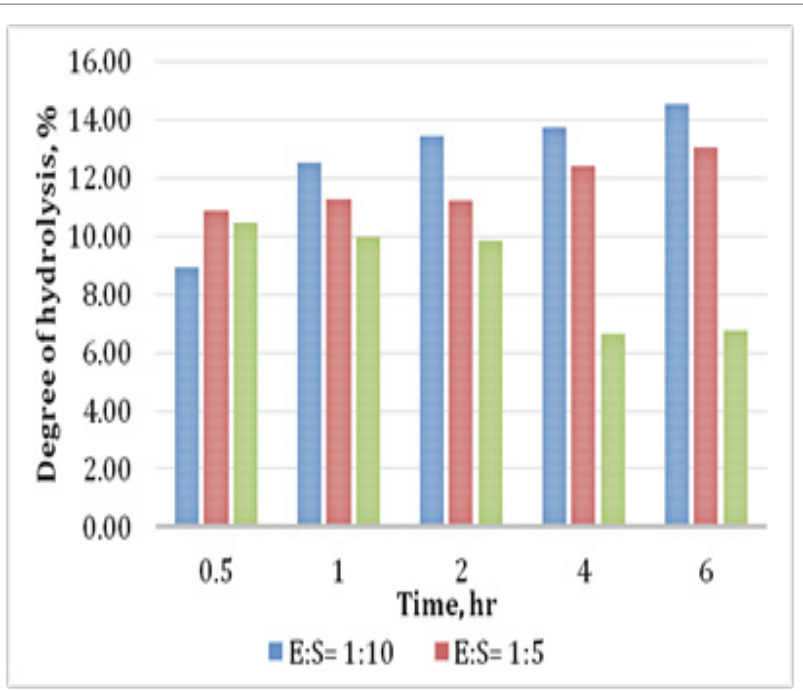

Figure 14 Effect of E-S ratio on soy protein hydrolysis.

Packed bed column for continuous hydrolysate production: Continuous protein hydrolysis process can be developed using packed bed column, immobilized serine endo-protease was packed in jacketed column. Hydrolysis of SPI was carried out by continuous supply of feed solution and recovering protein hydrolysate from other end of column (Figure 15). Continuous production of protein hydrolysate was possible with use of packed bed column, as reported by Ge et al. ${ }^{18}$ for production of whey protein hydrolysate ${ }^{18}$ and BSA hydrolysis by immobilized acid protease. ${ }^{47}$ The experimental setup produced homogeneous protein hydrolysate (with same degree of hydrolysate) for 10-15 cycles without affecting catalytic activity of protease. Soy protein hydrolysis was studied at substrate concentration $25 \mathrm{mg} / \mathrm{ml}$ at $50^{\circ} \mathrm{C}$ with respect to residence time $(2-120 \mathrm{~min})$ by varying feed flow rates in packed bed column (Figure 16), results obtained in column hydrolysis were comparable to batch mode with same enzyme load. Thus immobilized preparation can be utilized in continuous protein hydrolysis.

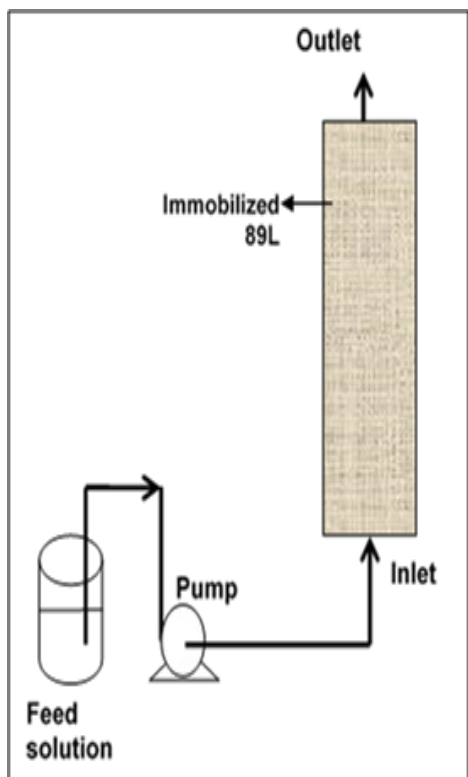

Figure I5 Packed bed column hydrolysis of proteins with immobilized 89L.

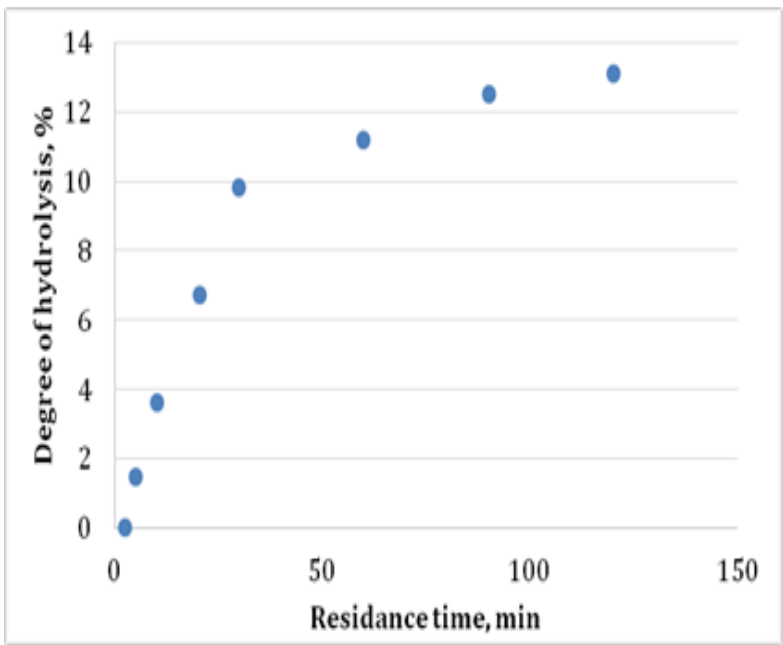

Figure 16 Effect of residence on soy protein hydrolysis.

Mass spectrometry analysis for soy protein hydrolysate: High resolution mass spectrometry analysis was carried out to confirm presence of low molecular weight peptides in soy protein hydrolysate. This approach involves identification of peptides with proteomic database searching based on peptide masses obtained from digested proteins and helps in recognising parent proteins. ${ }^{48}$ Sample was eluted in gradient mode with $0.1 \%$ formic acid (A) and $90 \% \mathrm{ACN}$ with $0.1 \%$ formic acid; starting with $5 \% \mathrm{~B}, 15 \% \mathrm{~B}$ in $3 \mathrm{~min}, 35 \% \mathrm{~B}$ in $40 \mathrm{~min}$, $60 \% \mathrm{~B}$ in $50 \mathrm{~min}$ and $95 \% \mathrm{~B}$ in $55 \mathrm{~min}$ followed by column wash for $10 \mathrm{~min}$ at $0.3 \mu \mathrm{l} / \mathrm{min}$ flow rate. MS data analysis using spectrum mill software confirmed presence of peptides with molecular weight about $\leq 1 \mathrm{kDa}$ and chain length of 10-23 amino acid residues. Total 15 identified peptides are listed in Table 3 . These peptides were derived from glycinin, conglycinin, lipoxygenases, trypsin inhibitor etc. Future work involves detailed analysis of soy protein hydrolysates with respect to its peptide profiling. 
Table 3 Peptides present in soy protein hydrolysate

\begin{tabular}{|c|c|c|c|c|c|}
\hline $\begin{array}{l}\text { Sr. } \\
\text { no. }\end{array}$ & Peptide sequence & $\begin{array}{l}\text { Peptide } \\
\text { weight } \\
(\mathrm{kDa})\end{array}$ & Parent protein & Score & $\begin{array}{l}\text { Accession } \\
\text { number }\end{array}$ \\
\hline 1 & TDIISKISPLPVLKE & 1.65 & $\begin{array}{l}\text { Seed linoleate } \\
\text { 9S-lipoxygenase-3 }\end{array}$ & 18.25 & P09186 \\
\hline 2 & RDVISTIIPLPVIKE & 1.69 & $\begin{array}{l}\text { Seed linoleate } \\
\text { |3S-lipoxygenase- I }\end{array}$ & 18.02 & P08I70 \\
\hline 3 & GSEEEDEDEDEEQDERQFPFPRPPHQKE & 3.42 & $\begin{array}{l}\text { beta-Conglycinin-alpha- } \\
\text { chain }\end{array}$ & 17.45 & PI39I6 \\
\hline 4 & TEVISTIMPLPVVKE & 1.65 & $\begin{array}{l}\text { Seed linoleate } \\
\text { 9S-lipoxygenase-2 }\end{array}$ & 17.06 & P09439 \\
\hline 5 & TDIISKISPLPVLK & 1.52 & $\begin{array}{l}\text { Seed linoleate } \\
\text { 9S-lipoxygenase-3 }\end{array}$ & 15.03 & P09186 \\
\hline 6 & TIIPLPVIKE & 1.12 & $\begin{array}{l}\text { Seed linoleate } \\
\text { |3S-lipoxygenase- I }\end{array}$ & 14.24 & P08I70 \\
\hline 7 & TEWSVVEDLPEGPAVKI & 1.86 & Trypsin inhibitor A & 13.77 & POI070 \\
\hline 8 & LVSESETEKITLEPGDMIHIPAG & 2.46 & Sucrose binding protein & 13.39 & Q04672 \\
\hline 9 & LDIFLSSVDINE & 1.36 & $\begin{array}{l}\text { beta-Conglycinin-beta- } \\
\text { chain }\end{array}$ & 12.04 & P25974 \\
\hline 10 & TATSLDFPALS & 1.12 & Glycinin GI & 11.89 & P04776 \\
\hline II & LDFPALSWLRL & 1.33 & Glycinin GI & 11.84 & P04776 \\
\hline 12 & ELSEDDVFVIPAA & 1.4 & $\begin{array}{l}\text { beta-Conglycinin-beta- } \\
\text { chain }\end{array}$ & 11.67 & P25974 \\
\hline 13 & YRAELSEDDVFVIPAA & 1.79 & $\begin{array}{l}\text { beta-Conglycinin-beta- } \\
\text { chain }\end{array}$ & 11.14 & P25974 \\
\hline 14 & GSKDNVISQIPSQVQELA & 1.91 & $\begin{array}{l}\text { beta-Conglycinin-alpha'- } \\
\text { chain }\end{array}$ & 10.33 & $\mathrm{PI} \mid 827$ \\
\hline 15 & SEDDVFVIPAA & 1.16 & $\begin{array}{l}\text { beta-Conglycinin-beta- } \\
\text { chain }\end{array}$ & 10.26 & P25975 \\
\hline
\end{tabular}

\section{Conclusion}

Glutaraldehyde coupling was found to be suitable for immobilizing serine endo protease 89L. Glutaraldehyde concentration, enzyme loading was found to influence proteolytic activity of immobilized 89L; systematic optimization studies lead to enhancement of specific activity up to $9260 \mathrm{CDU} / \mathrm{mg}$ of protein. Immobilized $89 \mathrm{~L}$ showed higher tolerance to $\mathrm{pH}$ and temperature conditions in comparison to soluble enzyme with improved storage and operational stability. For controlled protein hydrolysis; substrate concentration, enzyme loading and reaction time are key parameters which determine fate of hydrolysis reaction. The enzymatic hydrolysis with immobilized protease generated peptides with molecular weight in the range of $1-10 \mathrm{kDa}$ and $<1 \mathrm{kDa}$ after $5 \mathrm{hrs}$ of hydrolysis. Formation of this low molecular weight peptide was proportional to progress of reaction, which was confirmed by analysing protein hydrolysates using gel permeation chromatography. Therefore controlled exposure of protease with substrate/s yields differential hydrolysis patterns thereby generating different types of peptides at various time periods. Establishing correlation between $\mathrm{DH}$ and molecular weight of peptide has helped in designing process parameters to obtain peptides with desired molecular weights and functional properties. Mass spectrometry analysis confirmed presence of low molecular weight peptides in soy protein hydrolysates that would be further utilized as cell growth stimulators.

\section{Acknowledgements}

This study was supported by the Department of Biotechnology, Ministry of India and Institute of Chemical Technology, Mumbai. We wish to express our gratitude to the DBT-ICT-Centre for Energy Biosciences for financial support.

\section{Conflict of interest}

The author declares no conflict of interest.

\section{References}

1.Panyam D, Kilara A. Enhancing the functionality of food proteins by enzymatic modification. Trends in Food Science \& Technology. 1996;7(4):120-125.

2. Wang Wei, Li ZhongLei, Liu JunZhong, et al. Comparison between thermal hydrolysis and enzymatic proteolysis processes for the preparation of tilapia skin collagen hydrolysates. Czech Journal of Food Sciences. 2013;31(1):1-4. 
3. Wang G, Wang T. Egg yolk protein modification by controlled enzymatic hydrolysis for improved functionalities. International Journal of Food Science \& Technology. 2009;44(4):763-769.

4. Xinhuai Zhao, Yao Hou. Limited hydrolysis of soybean protein concentrate and isolate with two proteases and the impact on emulsifying activity index of hydrolysates. African Journal of Biotechnology. 2009;8(14):3314-3319.

5. Lamsal BP, Jung S, Johnson LA. Rheological properties of soy protein hydrolysates obtained from limited enzymatic hydrolysis. $L W T$ - Food Science and Technology. 2007;40(7):1215-1223.

6. Pintado ME, Ana E Pintado, Xavier Malcata F. Controlled whey protein hydrolysis using two alternative proteases. Journal of Food Engineering. 1999;42(1):1-13.

7. Govindaraju K. Studies on the Preparation and Characterisation of Protein Hydrolysates From Groundnut and Soybean Isolates. Department Of Protein Chemistry And Technology. Mysore, India: Central Food Technological Research Institute; 2003.

8. Geisenhoff H. Bitterness of soy protein hydrolysates according to molecular weight of peptides. Food Science and Human Nutrition, USA: Iowa State University; 2009. p. 1-106.

9. Achouri A, Wang Zhang, Xu Shiying. Enzymatic hydrolysis of soy protein isolate and effect of succinylation on the functional properties of resulting protein hydrolysates. Food Research International. 1998;31(9):617-623

10. Barac MB, Jovanovic ST, Stanojevic SP, et al. Effect of limited hydrolysis on traditional soy protein concentrate. Sensors. 2006;6(9):1087-1101.

11. De la Barca AMC, Salazar RAR, Jara-Marini ME. Enzymatic hydrolysis and synthesis of soy protein to improve its amino acid composition and functional properties. Journal of Food Science. 2000;65(2):246-253.

12. Meinlschmidt P, Sussmann D, Schweiggert-Weisz U, et al. Enzymatic treatment of soy protein isolates: effects on the potential allergenicity, technofunctionality, and sensory properties. Food Sci Nutr. 2016;4(1):1123.

13. Sun XD. Enzymatic hydrolysis of soy proteins and the hydrolysates utilisation. International Journal of Food Science \& Technology 2011;46(12):2447-2459

14. Tsou MJ, Lin SB, Chao CH, et al. Enhancing the lipolysis-stimulating activity of soy protein using limited hydrolysis with Flavourzyme and ultrafiltration. Food Chem. 2012;134(3):1564-1570.

15. Tsumura K. Improvement of the physicochemical properties of soybean proteins by enzymatic hydrolysis. Food Science and Technology Research. 2009;15(4):381-388.

16. Engenharia E De, Doutoramento T De. Valorisation of the peptidic fraction of cheese whey; 2007.

17. Coelho Silvestre MP, Ramalho Silva M, Medeiros Silva VD, et al. Analysis of whey protein hydrolysates : peptide profile and ACE inhibitory activity. Braz J Pharm Sci. 2012;48(4):747-757.

18. Ge SJ, Bai H, Yuan HS, et al. Continuous production of high degree casein hydrolysates immobilized proteases in column reacto. $J$ Biotechnol. 1996;50(2-3):161-170

19. Kumar Sharma R, Jashbir Singh, Chauhan GS. Study of immobilization of protease and sorption of bsa on cellulose, cellulose derivatives, and graft copolymers. BioResources. 2010;5(4):2547-2555.

20. Cheryan M, Deeslie WD. Soy protein hydrolysis in membrane reactors. J Am Oil Chem Soc. 1983;60(6):1112-1115.

21. Chiang WD, Cordle CT, Thomas RL. Casein hydrolysate produced using a formed-in-place membrane reactor. Journal of Food Science. 1995;60(6):1349-1352.
22. Belhocine D, Mokrane H, Grib H, et al. Optimization of enzymatic hydrolysis of haemoglobin in a continuous membrane bioreactor. Chemical Engineering Journal. 2000;76(3):189-196.

23. Prieto CA, Guadix EM, Guadix A. Influence of temperature on protein hydrolysis in a cyclic batch enzyme membrane reactor. Biochemical Engineering Journal. 2008;42(3):217-223.

24. Anwar A, Saleemuddin M. Alkaline proteases: a review. Bioresource Technology. 1998;64(3):175-183.

25. Brena B, Pombo PG, Viera FB. Immobilization of enzymes: A literature survey. Immobilization of Enzymes and Cells. 2013;1051:15-31.

26. Datta S, Christena LR, Sriramulu Rajaram YR. Enzyme immobilization: an overview on techniques and support materials. 3 Biotech. 2012;3(1):1-9.

27. Benkhelifa H, Bengoa C, Larre C, et al. Casein hydrolysis by immobilized enzymes in a torus reactor. Process Biochemistry. 2005;40(1):461467.

28. Roger AS. Enzyme immobilization: The quest for optimum performance. Adv Synth Catal. 2007;349(8-9):1289-1307.

29. Betancor L, Gallego FL, Hidalgo A, et al. Different mechanisms of protein immobilization on glutaraldehyde activated supports: Effect of support activation and immobilization conditions. Enzyme and Microbial Technology. 2006;39(4):877-882.

30. Migneault I, Dartiguenave C, Bertrand MJ, et al. Glutaraldehyde: Behavior in aqueous solution, reaction with proteins, and application to enzyme crosslinking. Biotechniques. 2004;37(5):790-796.

31. Ferreira L, Ramos MA, Dordick JS, et al. Influence of different silica derivatives in the immobilization and stabilization of a Bacillus licheniformis protease (Subtilisin Carlsberg). Journal of Molecular Catalysis B. Enzymatic. 2003;21(4-6):189-199.

32. Bhandari S, Vijay Kumar Gupta, Hari Singh. Enhanced stabilization of mungbean thiol protease immobilized on glutaraldehyde-activated chitosan beads. Biocatalysis and Biotransformation. 2009;27(1):71-77.

33. Singh AN, Singh S, Suthar N, Dubey VK. Glutaraldehyde-activated chitosan matrix for immobilization of a novel cysteine protease, procerain B. J Agric Food Chem. 2011;59(11):6256-6262.

34. Ahmed SA, Saleh SA, Fattah A. Stabilization of Bacillus Licheniformis ATCC 21415 Alkaline Protease by Immobilization and Modification. Aust J Basic \& Appl Sc. 2007;1(3):313-322.

35. Bradford MM. A rapid and sensitive method for the quantitation of microgram quantities of protein utilizing the principle of protein-dye binding. Anal Biochem. 1976;72:248-254.

36. Roy JJ, Sumi S, Sangeetha K, et al. Chemical modification and immobilization of papain. J Chem Technol Biotechnol. 2005;80(2):184-188.

37. Nissen JA. Determination of the degree of hydrolysis of food protein hydrolysates by trinitrobenzenesulfonic acid. J Agric Food Chem. 19979;27(6):1256-1262.

38. Tanksale A, Chandra PM, Mala Rao, et al. Immobilization of alkaline protease from Conidiobolus macrosporus for reuse and improved thermal stability. Biotechnology Letters. 2011;23(1):51-54.

39. Tavano OL. Protein hydrolysis using proteases: An important tool for food biotechnology. Journal of Molecular Catalysis B: Enzymatic. 2013;90:1-11

40. Cunningham BC, Wells JA. Improvement in the alkaline stability of subtilisin using an efficient random mutagenesis and screening procedure. Protein Eng. 1987;1(4):319-325.

41. Adriano WS, Filho EHC, Silva JA, et al. Stabilization of penicillin G acylase by immobilization on glutaraldehyde-activated chitosan. Braz J Chem Eng. 2005;22(4):529-538. 
42. Kilinç A, Önal S, Telefoncu A. Stabilization of papain by modification with chitosan. Turk J Chem. 2002;26(2002):311-316.

43. Ruinatscha R, Karande R, Buehler K, et al. Integrated one-pot enrichment and immobilization of styrene monooxygenase (StyA) using SEPABEAD EC-EA and EC-Q1A anion-exchange carriers. Molecules 2011;16(7):5975-5988.

44. Anwar A, Ul Qader SA, Raiz A, et al. Calcium alginate: a support material for immobilization of proteases from newly isolated strain of bacillus subtilis KIBGE-HAS. World Applied Sciences Journal. 2009;7(10):1281-1286.

45. Kim HJ, Kim BK. Comparison of soy protein concentrates produced using membrane ultrafiltration and acid precipitation. Food Sci Biotechnol. 2015;24(1):67-73.
46. Wang SN, Zhang CR, Qi BK, et al. Immobilized alcalase alkaline protease on the magnetic chitosan nanoparticles used for soy protein isolate hydrolysis. Eur Food Res Technol. 2014;239(6):1051-1059.

47. Kumar AG, Perinbam K, Kamatchi P, et al. In situ immobilization of acid protease on mesoporous activated carbon packed column for the production of protein hydrolysates. Bioresource Technology. 2010;101(4):13771379.

48. Migneault I, Dartiguenave C, Vinh J, et al. Comparison of two glutaraldehyde immobilization techniques for solid-phase tryptic peptide mapping of human hemoglobin by capillary zone electrophoresis and mass spectrometry. Electrophoresis. 2004;25(9):1367-1378.

49. Rathi K. Design and scale up of enzymatic biotransformation. India: Institute of Chemical Technology; 2014. 